\title{
Molecular Imaging in Breast Cancer - Potential Future Aspects
}

\author{
Katja Pinker ${ }^{\mathrm{a}}$ Wolfgang Bogner ${ }^{\mathrm{a}, \mathrm{b}}$ Stephan Gruber ${ }^{\mathrm{a}, \mathrm{b}} \quad$ Peter Brader $^{\mathrm{a}}$ \\ Siegfried Trattnig ${ }^{a, b}$ Georgios Karanikas ${ }^{c}$ Thomas H. Helbich ${ }^{a}$ \\ aUniversitätsklinik für Radiodiagnostik, Division für Molekulare und Gender Bildgebung, \\ ${ }^{\mathrm{b}}$ MR Exzellenzzentrum, Universitätsklinik für Radiodiagnostik, \\ 'Universitätsklinik für Nuklearmedizin, Medizinische Universität Wien, Austria
}

\section{Keywords}

Molecular imaging · Breast cancer · PET-MRI .

Multiparametric MRI · Nuclear imaging

\section{Summary}

Molecular imaging aims to visualize and quantify biological, physiological, and pathological processes at cellular and molecular levels. Recently, molecular imaging has been introduced into breast cancer imaging. In this review, we will present a survey of the molecular imaging techniques that are either clinically available or are being introduced into clinical imaging. We will discuss nuclear imaging and multiparametric magnetic resonance imaging as well as the combined application of molecular imaging in the assessment of breast lesions. In addition, we will briefly discuss other evolving molecular imaging techniques, such as phosphorus magnetic resonance spectroscopic imaging and sodium imaging.

\section{Introduction}

Molecular imaging aims to visualize and quantify biological, physiological, and pathological processes at cellular and molecular levels [1]. Within the recent years, molecular imaging has entered the field of breast imaging and has been established as another imaging modality to detect and to further elucidate the development and progression and treatment response of breast cancer. Molecular imaging of the breast is able to visualize the tumor morphology and functional and

\author{
Schlüsselwörter \\ Molekulare Bildgebung · Mammakarzinom · \\ PET-MRT · Multiparametrische MRT . \\ Nuklearmedizinische Bildgebung
}

\section{Zusammenfassung}

Die molekulare Bildgebung beschäftigt sich mit der Darstellung, Beschreibung und Quantifizierung von biologischen, physiologischen und pathologischen Prozessen auf zellulärer und molekularer Ebene. In der letzten Zeit hat die molekulare Bildgebung begonnen, sich auch in der Mammadiagnostik zu etablieren. Im Rahmen dieses Artikels soll ein Überblick über die molekularen Bildgebungstechniken gegeben werden, die entweder in der Klinik verfügbar sind oder die gerade in die klinische Bildgebung eingeführt werden. Dabei werden die nuklearmedizinische Bildgebung und die multiparametrische Magnetresonanztomographie sowie die kombinierte Anwendung molekularer Bildgebungstechniken bei der Untersuchung von Brustläsionen besprochen. Außerdem werden wir kurz andere in der Entwicklung befindliche molekulare Bildgebungstechniken wie die Phosphor-Magnetresonanzspektroskopie und die Natrium-Bildgebung erläutern.

metabolic processes within the tumor at different levels, giving insight into pathological processes such as neovascularity, apoptosis, and necrosis (fig. 1). Today, molecular imaging techniques comprise both nuclear-medical as well as radiological techniques. This review will provide a survey of both the current and the evolving techniques in molecular imaging. First, we will discuss molecular imaging of breast cancer with established nuclear imaging methods, such as breast-specific gamma imaging (BSGI) and positron emission mammography (PEM) and the currently used nonspecific radiotracers. We

\section{KARGER}

Fax +497614520714

Information@Karger.de

www.karger.com
(C) 2011 S. Karger GmbH, Freiburg

$1661-3791 / 11 / 0062-0110 \$ 38.00 / 0$

Accessible online at:

www.karger.com/brc
Thomas Helbich, MD, MSc, MBA

Medizinische Universität Wien, Universitätsklinik für Radiodiagnostik

Abteilung für Allgemeine Radiologie und Kinderradiologie,

Division für Molekulare und Gender Bildgebung

Währinger Gürtel 18-20, 1090 Wien, Austria

Tel.+43 1 40400-4818, Fax -4898

thomas.helbich@meduniwien.ac.at 


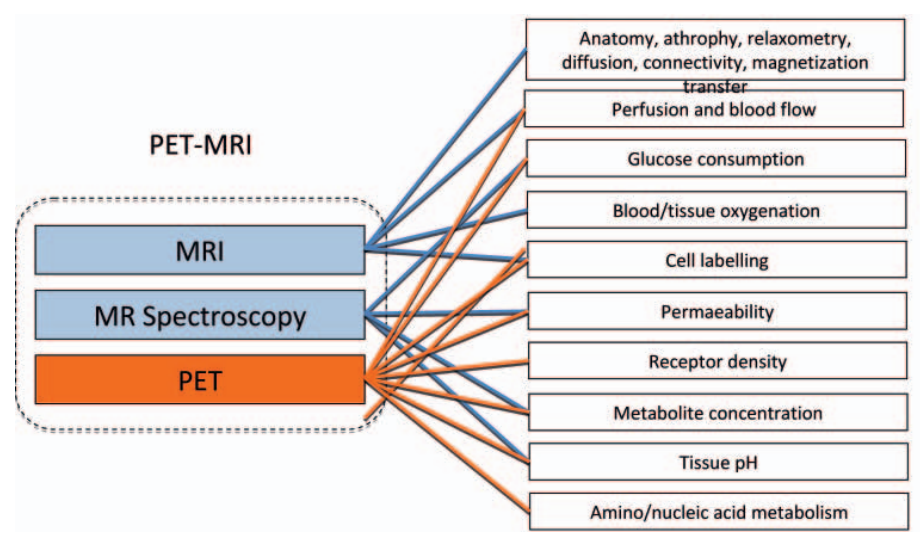

will further explore molecular imaging of breast cancer applying multiparametric magnetic resonance imaging (MRI) techniques (contrast-enhanced MRI (CE-MRI); diffusionweighted imaging (DWI); proton magnetic resonance spectroscopic imaging $\left({ }^{1} \mathrm{H}-\mathrm{MRSI}\right)$; phosphorus MRSI $\left({ }^{31} \mathrm{P}-\mathrm{MRSI}\right)$; sodium imaging) and discuss their clinical applications.

Finally, we will review evolving molecular imaging of breast cancer with positron emission tomography (PET)MRI, the combined application of nuclear-medical and radiological imaging techniques in the assessment of breast lesions, and briefly discuss the application of specific radiotracers allowing tailored cancer detection and therapy monitoring.

\section{Nuclear Imaging of Breast Cancer}

Today, mammography is the imaging modality of choice for breast cancer screening. The overall sensitivity of mammography has been reported to be $78-85 \%$; however, the sensitivity of mammography decreases to $42-68 \%$ in women with dense breasts [2]. In addition, the false-positive rate of screening mammography is $15-30 \%$, leading to many benign findings at biopsy. Thus, these limitations in both sensitivity and specificity of screening mammography led to the investigation of adjunct breast imaging modalities, such as nuclear breast imaging, which focus on the visualization of both morphological and metabolic changes in the breast.

\section{Breast-specific gamma imaging}

Nuclear-medical methods for breast imaging have existed since the early 1990s, when it was discovered that the radiotracer technetium-99m (99mTc) sestamibi can be used to image breast cancer with a technique called scintimammography, acquiring images similar to mammography in the craniocaudal (CC) and mediolateral-oblique (MLO) projection [3, 4]. The use of $99 \mathrm{mTc}$ sestamibi for breast cancer detection was reported by Aktolun et al. [5] in 1992 during its evaluation as cardiac imaging agent. In 1994, Khalkhali et al. [6] reported on $99 \mathrm{mTc}$ sestamibi scintimammography in patients with suspected breast cancer. Since then, multiple techniques
Fig. 1. The combination of PET and MRI offers a multitude of functional information, which can be acquired at the same time; PET and functional MR data complement each other along with high-resolution anatomy (modified from [133]). using both planar and single-photon emission computed tomographic radionuclide imaging with a general-purpose gamma camera for the detection of breast cancer have been evaluated. These techniques have yielded an average sensitivity of $84 \%$ and a specificity of $86 \%$, as reported by Taillefer [7] in a meta-analysis of 5660 patients. In comparison with mammography, the sensitivity of $99 \mathrm{mTc}$ sestamibi scintimammography is independent of breast density [8-10]. In addition, scintimammography has not shown increased uptake in women with architectural distortion or scarring from a prior procedure [11]. 99mTc sestamibi scintimammography performed with a general-purpose gamma camera is limited by the inability to reliably image cancers smaller than $1 \mathrm{~cm}$, owing to its intrinsic resolution with a sensitivity for these lesions of 35-65\% [12-17]. Accounting for these limitations in resolution and the design of the traditional gamma camera for breast imaging, high-resolution breast-specific gamma cameras have been developed (fig. 2a, b). The use of high-resolution, small-field-of-view BSGI has been shown to increase the sensitivity of nuclear breast imaging [18-21]. One study demonstrated an increase in sensitivity from 85 to $92 \%$ for lesions larger than $1 \mathrm{~cm}$ and from 47 to $67 \%$ for lesions smaller than $1 \mathrm{~cm}$, when using BSGI as compared with a general-purpose gamma camera [18]. Cancers as small as $6 \mathrm{~mm}$ were detected with the high-resolution gamma camera when screening women at increased risk for breast cancer [19]. In another study, Brem et al. [22] retrospectively determined the sensitivity and specificity of BSGI for the detection of breast cancer by using pathological results as the standard of reference. In this study, they investigated 146 patients with 167 lesions (84 malignant, 83 benign) with BSGI. BSGI has high sensitivity (96.4\%) and moderate specificity (59.5\%), helping detect breast cancers. The smallest invasive cancer and ductal carcinoma in situ (DCIS) detected both measured $1 \mathrm{~mm}$. BSGI helped detect occult cancers not visualized at mammography or ultrasonography in 6 patients. In a most recent study, Brem et al. [23] confirmed their findings on occult cancers not visualized at mammography or ultrasonography. They investigated how often BSGI identifies occult cancerous lesions in women with 1 suspicious lesion detected on 


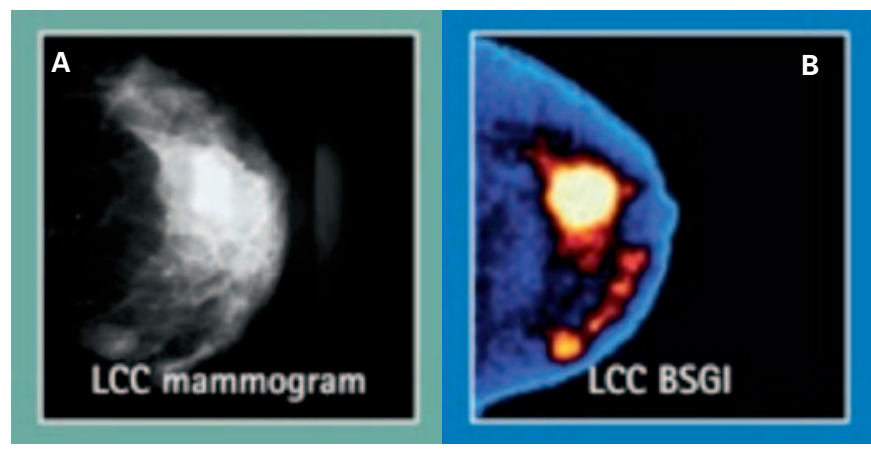

Fig. 2. Visualization of a multicentric invasive ductal carcinoma of the left breast with $(\mathbf{A})$ digital mammography and $(\mathbf{B})$ color-coded breast-specific gamma camera: Both the index and the satellite lesions are markedly hypermetabolic. Courtesy of Dilon Diagnostics.

mammography or physical exam. BSGI detected additional suspicious lesions occult to mammography and physical exam in $29 \%$ of these cases. BSGI identified occult cancer in $35 \%$ of cases who underwent biopsy or excision because of BSGI findings and in $9 \%$ of the women in this study. Brem et al. concluded that BSGI allows an accurate identification of mammographically and clinically occult cancer in women with 1 suspicious breast lesion, rendering BSGI a valuable tool in the detection and characterization of both symptomatic and clinically occult malignant breast lesions.

\section{Positron Emission Mammography}

PET with [F-18]-fluorodeoxyglucose ([F-18]-FDG) can depict areas of increased glucose metabolism and is capable of demonstrating radiologically occult malignancy [24]. This imaging modality is increasingly used in oncological imaging to depict metastasis and recurrent carcinoma. Several studies have evaluated [F-18]-FDG-PET imaging of primary breast carcinoma. Findings from these studies indicated that the majority of these malignancies manifest increased glucose metabolism and can be imaged with [F-18]-FDG-PET [2428]. Results of studies performed with conventional wholebody PET scanners have substantiated that [F-18]-FDG-PET imaging has a sensitivity similar to that of conventional techniques in demonstrating primary and recurrent breast cancer. Results from these studies also have established that [F-18]FDG-PET imaging has a higher specificity (fewer false-positive results) than conventional techniques, including MRI. The high specificity of [F-18]-FDG-PET for breast carcinomas may have particular clinical value because all other current breast imaging modalities, including conventional mammography, ultrasonography and MRI, have low specificity for depicting malignancy [28-30]. [F-18]-FDG-PET imaging, however, is not routinely used for local staging of known or suspected primary breast malignancies. Although imaging studies performed with whole-body PET imaging scanners have established the feasibility of using [F-18]-FDG-PET to identify and characterize breast malignancy, findings from these same studies also highlight the limitations that are inherent in currently available PET imaging techniques. Specifically, whole-body PET scanners have a limited ability to depict small lesions, and breast abnormalities that are demonstrated with these scanners can be difficult to localize anatomically. Moreover, whole-body PET is expensive, and while the number of scanners is increasing rapidly, access to this modality, when compared with conventional mammography for example, is still limited. Recently, in an attempt to overcome the limitations of whole-body PET for the depiction of breast cancer, a PET imaging system exclusively for breast imaging has been developed - the so called positron emission mammography (PEM) [31, 32]. Dedicated PEM units that can image positron-emitting tracers in the breast have several potential benefits over whole-body tomography, including high sensitivity for the emitted radiation, improved spatial resolution, substantially reduced attenuation, and reduced cost [31,33]. These dedicated units are also much more compact than conventional PET units and could be incorporated into a breast imaging facility, thereby making such units more readily available than whole-body PET units. In a pilot study, Rosen et al. prospectively assessed a dedicated, large-field-of-view PEM device for imaging primary breast carcinoma in 23 patients, and they concluded that PEM can demonstrate small primary breast malignancies [34, 35]. Another PEM pilot study in breast cancer, which used a 10 -mm crystal, was published in 2005. In 23 of the 44 women with confirmed breast cancers, 39 of the 44 primary index tumors were seen. In addition, of the 19 patients who were undergoing breast-conserving surgery, PEM correctly predicted $75 \%$ of patients with positive margins and $100 \%$ with negative margins. The authors concluded that PEM showed promise in detecting breast malignancies and assisted in planning breast-conserving surgery [36]. The results of a second, larger multicenter study that examined the performance efficacy of PEM in women with known breast cancer or suspicious mammography findings were published in 2006 [37]. In non-diabetic patients with proven breast cancer, PEM was found to have a cancer detection sensitivity of $91 \%$, a specificity of $93 \%$, a negative predictive value (NPV) of $88 \%$, and an accuracy of $92 \%$. Most importantly, PEM accurately identified $91 \%$ of the cases of DCIS preoperatively. In this study, 36 of 73 biopsies (49\%) prompted by conventional imaging alone proved to be benign; however, combining conventional imaging with PEM resulted in few false positives, with a positive predictive value (PPV) of $95 \%$. This finding highlights the advantage of combining anatomic and metabolic characterization in cancer detection. A recent article by Schilling et al. [38] reviewed the role of PEM in breast cancer imaging and management, and they concluded that with the promising results of PEM the ultimate goal in molecular imaging is to image the in vivo cancer biology of an individual to allow therapy to be personalized. The introduction of new positronemitting imaging agents such as the cell proliferation markers 
[F-18]-fluoro-L-thymidine (FLT) and [F-18]- or [C-11]-2'fluoro-5-methyl-1- $\beta$-D-arabinofuranosyluracil (FMAU) and [F-18]-fluoromisonidazole (FMISO), a radiotracer marker for tumor hypoxia, offers new opportunities for evaluating breast cancer and might help to achieve this goal. The authors conclude that the current data would suggest that positron radiotracer development and PET/PEM imaging technologies are in their infancy; however, combined, they are bringing us closer to personalized cancer therapy.

\section{Multiparametric High-Field (3 T) MRI of Breast Lesions}

Over the past decade, CE-MRI of the breast has evolved as a non-invasive imaging modality with a multitude of indications in breast diagnostics [39-45]. CE-MRI of the breast has a reportedly excellent sensitivity $(88-100 \%)$ but a rather variable specificity ranging from 37-97\% [43, 46-57]. Consequently, several successful attempts to increase the sensitivity, but especially the specificity, have been made. It has been demonstrated that the employment of high-resolution imaging protocols at a higher field strength and the additional application of functional and metabolic imaging techniques such as ${ }^{1} \mathrm{H}-\mathrm{MRSI}$ and DWI aid in the differentiation of benign and malignant lesions and increase specificity [58-69].

\section{High-Spatial- and High-Temporal-Resolution MRI of the Breast at $3 T$}

Several studies have demonstrated that, for the optimal diagnosis of breast lesions, an accurate assessment of both lesion morphology and enhancement kinetics is necessary [43, 46, $50,52,54,55,70,71]$. Although recent studies by Kuhl et al. and Goto et al. imply that a high spatial resolution improves diagnostic confidence and accuracy with MRI, a high temporal resolution is pivotal for the accurate assessment of lesion enhancement kinetics, which adds important information for the differentiation between malignant and benign lesions [53, 71-75]. Thus, the optimal imaging protocol should combine both high temporal and high spatial resolution. High-spatialresolution images must be acquired within a short time span to enable an optimal contrast in the arterial phase between the enhancing lesion and the adjacent breast parenchyma, and, due to reasons related to the signal-to-noise ratio (SNR), the maximum achievable spatial resolution at $1.5 \mathrm{~T}$ is limited $[51,76]$. One way to overcome these limitations is the application of parallel imaging techniques. The associated up to $30 \%$ SNR penalty is a limiting factor for the use of parallel imaging techniques at $1.5 \mathrm{~T}$. In recent years, high-field scanners operating at $3 \mathrm{~T}$ have entered the clinical practice and, compared to $1.5 \mathrm{~T}$, offer the advantage of a higher SNR, which can provide either a higher spatial resolution or faster imaging strategies. This offers the possibility to resolve the 'temporal versus spatial dilemma' faced by current breast MRI protocols with $1.5 \mathrm{~T}$ [51, 76-79]. In a recent study, Pinker et al. developed a $3.0 \mathrm{~T}$ breast imaging protocol that combined high-temporal- and high-spatial-resolution 3-dimensional (3D) MR sequences for quantitative time course and morphological analysis of breast lesions. In this study, the authors demonstrated that a combined high-temporal- and highspatial-resolution MRI protocol at $3 \mathrm{~T}$ enabled an accurate detection and assessment of breast lesions. These findings are concordant with the few reports in the literature about MRI of the breast at $3 \mathrm{~T}[51,55,76,80,81]$. Rakow-Penner et al. [81] assessed T1 and T2 relaxation times at $3 \mathrm{~T}$ in healthy volunteers. In an initial patient study, Kuhl et al. [76] concluded that dynamic CE-MRI of the breast at $3 \mathrm{~T}$, compared to $1.5 \mathrm{~T}$, yields excellent image quality as a receiver operating characteristics (ROC) analysis demonstrated that a higher specificity could be obtained.

\section{MRSI of Breast Lesions}

It has been demonstrated that the additional application of ${ }^{1} \mathrm{H}-\mathrm{MRSI}$ to CE-MRI aids in the differentiation of benign and malignant lesions [59-66, 82, 83]. The additional diagnostic value of ${ }^{1} \mathrm{H}$-MRSI of the breast is typically based on the detection of elevated choline (Cho) levels, since Cho is a biomarker for active tumors. There is no Cho peak in normal breast tissue at a field strength of 1.5 or $3 \mathrm{~T}[59,64,84]$. ${ }^{1} \mathrm{H}$-MRSI of the breast is usually performed on clinical magnets with a field strength of $1.5 \mathrm{~T}$, using dedicated breast coils and single-voxel localization. Limitations of this technique are the restriction to evaluating only 1 lesion at a time and that fine tumor heterogeneity cannot be assessed due to the relatively poor spatial resolution. Several studies performed on 1.5-T MR scanners reported sensitivities of $70-100 \%$ and specificities of $67-100 \%$ for ${ }^{1} \mathrm{H}-\mathrm{MRSI}$ of the breast [85-90]. In a recent study, Bartella and Huang [59] reported that single-voxel ${ }^{1} \mathrm{H}$-MRSI of the breast can be incorporated into the clinical 1.5-T breast MRI protocol with an additional imaging time of only $10 \mathrm{~min}$. They stated that the use of $\mathrm{H}^{1}$-MRSI of the breast, in conjunction with CE-MRI of the breast, significantly increases the PPV of MRI and decreases the number of benign biopsy results. They concluded that, in the future, ${ }^{1} \mathrm{H}$-MRSI will enable the examination of the whole breast and, with the use of higher field strengths, the evaluation of smaller lesions will also be feasible [67]. In a pilot study, Gruber et al. [91] developed a high-spatial-resolution 3D-MRSI protocol at $3 \mathrm{~T}$, designed to cover a large fraction of the breast in a clinically acceptable measurement time of 12-15 min. They concluded that 3D-MRSI at $3 \mathrm{~T}$ in patients with breast lesions is possible with excellent data quality and thus has the potential to become a valuable adjunct to CEMRI of the breast for differentiation of benign and malignant breast lesions (fig. 3).

Today, most MRI is performed on the ${ }^{1} \mathrm{H}$ nucleus; however, other nuclei can be imaged as well. Phosphorus MRSI $\left({ }^{31} \mathrm{P}-\mathrm{MRSI}\right)$ provides a window for assessing tissue bioenergetics and the metabolism of membrane phospholipids. In- 
deed, the significance of signals derived from phospholipid precursors and catabolites as biochemical markers for tumor progression and treatment response has been demonstrated $[92,93]$. It has been proven by in vitro and in vivo ${ }^{31} \mathrm{P}-\mathrm{MRSI}$ studies that high levels of phosphatidylcholine (PC)/phosphatidylethanolamine (PE) can be detected in several cancers whereas low levels are found in healthy parenchyma. A significant decrease in the $\mathrm{PE} / \mathrm{PC}$ ratio in malignant compared with benign tumors has been reported [94], and changes in the $\mathrm{PE} / \mathrm{PC}$ ratios (significant increase in the PE peak relative to the PC peak) have been observed during and after chemotherapy or radiation therapy. Although several clinical and experimental studies have reported alterations in phospholipid metabolism energetics and $\mathrm{pH}$ in tumors, the low sensitivity of ${ }^{31} \mathrm{P}$-MRSI restricts its clinical application to relatively large and primarily superficial tumors in the clinical setting $[95,96]$. Further studies and significant improvements in MR hardware and software are warranted to reveal the true potential of ${ }^{31} \mathrm{P}$-MRSI in breast cancer imaging.

\section{Diffusion-Weighted Imaging}

DWI provides information about the local microstructural characteristics of the diffusivity of water molecules in tissues, which is quantified using the apparent diffusion coefficient (ADC). Decreased diffusivity in the tissue correlates with a low ADC value. DWI is primarily used in the clinical routine for the early detection of cerebral ischemia [97]; however, changes in tissue water diffusion properties can be helpful for the detection and characterization of pathological processes in any part of the body [98]. In general, cancer tends to have a more restricted diffusion and lower ADC values than does normal tissue because of the high cell densities and abundance of intra- and intercellular membranes in cancer [67, 68, 99]. In recent years, the application of DWI in the clinical routine was limited to examinations of the brain [97] because of technical difficulties but, due to new developments in imaging techniques (e.g. parallel imaging) and hardware (e.g. stronger gradient systems and multi-channel coils), these limitations (e.g. susceptibility and respiratory motion artifacts) can be overcome [100]. Hence, in the last several years, the potential of DWI for clinical diagnostics, especially for tumor identification, has been shown for several organs, e.g. liver, kidneys, pancreas, prostate, breast, etc. [101, 102], and the whole body [103-108].

In recent years, the application of DWI in breast cancer imaging has been evaluated by several studies [109-111], and it was demonstrated that breast cancer showed lower ADC values for breast cancer compared to healthy breast tissue. Guo et al. [110] showed the statistical difference in ADC values between malignant and benign lesions and a high accuracy of ADC in the differentiation of breast tumors, with a sensitivity of $93 \%$ and a specificity of $88 \%$. In another study, Woodhams et al. used breast DWI to diagnose breast cancer and identify cancer extension. They concluded that DWI is a

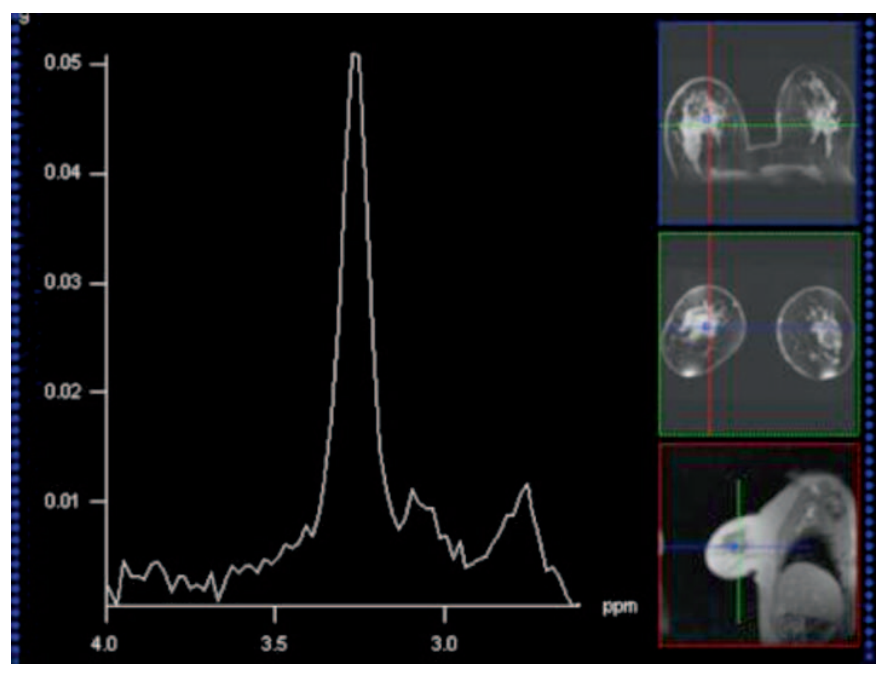

Fig. 3. 54-year-old patient with invasive ductal carcinoma G2 of the right breast. ${ }^{1} \mathrm{H}$-MRS spectrum of the breast cancer with a Cho peak at $3.2 \mathrm{ppm}$. Spectra obtained at $3 \mathrm{~T}$ by using a ${ }^{1} \mathrm{H}$-MRSI sequence with point resolved spectroscopy (PRESS) preselection (repetition time/echo time $(\mathrm{TR} / \mathrm{TE})=750 / 145 \mathrm{~ms})$. The sequence included spectral water and fat suppression and spatial outer volume suppression. Voxel size was $1 \times 1 \times 1 \mathrm{~cm}$ in all measurements.

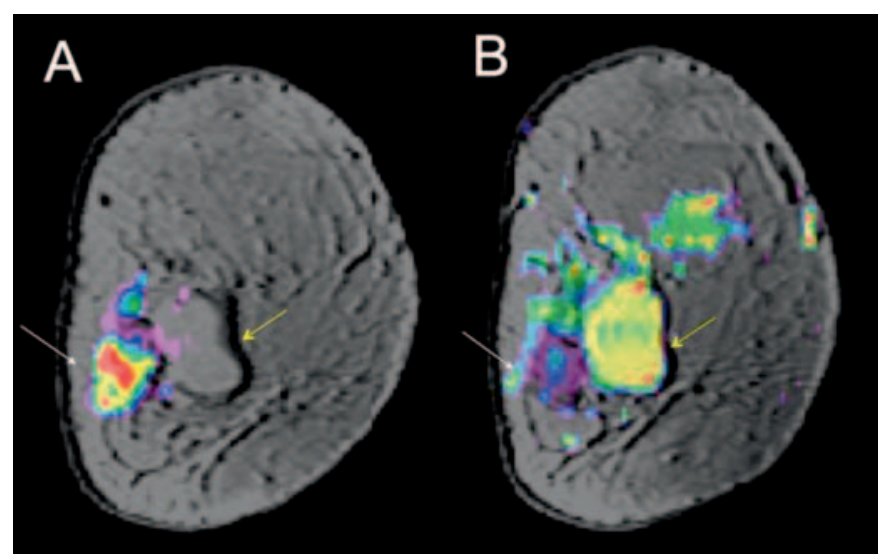

Fig. 4. 61-year-old patient with invasive ductal carcinoma G2 of the left breast adjacent to a simple cyst. (A) Color-coded diffusion-weighted image $\left(b=850 \mathrm{~s} / \mathrm{mm}^{2}\right)$ overlaid on a high-spatial-resolution morphologic T1-weighted MR image demonstrating restricted diffusion; (B) low ADC values on a color-coded ADC map. The simple cyst demonstrates no decreased ADC values. ADC map derived from $\mathrm{b}=50$ and $850 \mathrm{~s} / \mathrm{mm}^{2}$ $\left(\right.$ mean \pm standard deviation $\left.(\mathrm{SD})=(0.78 \pm 0.16) \times 10^{-3} \mathrm{~mm}^{2} / \mathrm{s}\right)$ in the same region as a marker of lesion malignancy.

promising adjunct tool in breast cancer assessment that provides additional functional information to the information from routine MRI and MRSI and can be easily inserted into a standard MRI protocol $[69,112]$. In a more recent study, Bogner et al. compared the diagnostic quality of DWI schemes with regard to ADC accuracy, ADC precision, and DWI contrast-to-noise ratio (CNR) for different types of lesions and breast tissue at $3 \mathrm{~T}[67,99]$. They concluded that optimum ADC determination and DWI quality at 3.0 T was 
found with a combined b-value protocol of 50 and $850 \mathrm{~s} / \mathrm{mm}^{2}$. This provided a high accuracy for the differentiation of benign and malignant breast tumors (fig. 4a-c).

\section{Sodium MRI $\left({ }^{23} \mathrm{Na}-\mathrm{MRI}\right)$}

Another promising MRI technique beyond anatomical imaging is sodium imaging $\left({ }^{23} \mathrm{Na}-\mathrm{MRI}\right)$ which provides information on physiology and cellular metabolism [113-116]. Sodium imaging yields information that reflects the physiological and biochemical state of diseased tissue and the sodium concentration is a sensitive indicator of cellular and metabolic integrity and ion homeostasis [116-120]. In normal cells, a low intracellular sodium concentration is maintained by the $\mathrm{Na}^{+} /$ $\mathrm{K}^{+}$-ATPase pump actively pumping sodium out of the cell against a concentration gradient formed by the much higher extracellular sodium concentration. If the ATP supply is insufficient due to impaired cellular energy metabolism or due to compromised cellular integrity, the intracellular sodium levels rise sharply. ${ }^{23} \mathrm{Na}-\mathrm{MRI}$ can detect these elevated sodium levels after exhaustive exercise, but also in various diseases such as myocardial infarction and cancer. Ouwerkerk et al. [118] investigated the potential of ${ }^{23} \mathrm{Na}-\mathrm{MRI}$ for the differentiation of benign and malignant breast lesions and concluded that elevated tissue sodium concentrations (TSC) in breast lesions appear to be a cellular-level indicator associated with malignancy, and thus may have the potential to increase the specificity of breast MRI. However, further studies, as well as improvements in MR hardware and software, are warranted to elucidate the true potential of ${ }^{23} \mathrm{Na}-\mathrm{MRI}$ in cancer imaging.

\section{Molecular Imaging with PET-MRI}

\section{PET-MRI}

During the past decade, the application of PET has remarkably improved the management of breast cancer patients. The most commonly used radiotracer is [F-18]-FDG. [F-18]-FDGPET is of increasing value in the differentiation of benign and malignant breast lesions, in disease staging, and in the assessment of treatment response [121, 122], as it provides functional data on the tumor metabolism and has been found to be of complementary value to morphological imaging studies when assessing lymph node involvement as well as distant metastases [123]. [F-18]-FDG-PET also plays a role in the monitoring of primary chemotherapy in locally advanced breast cancer, where it allows the prediction of the response shortly after the onset of therapy by monitoring therapy-induced changes in tumor metabolism [124, 125]. Thus, [F-18]FDG-PET may be helpful in making decisions about continuation, modification or cessation of therapy. However, limited anatomical information and low spatial resolution in [F-18]FDG-PET images frequently render the localization of a lesion difficult and may compromise the assessment of potential tumor infiltration into adjacent organs. In order to overcome these limitations, combined molecular imaging systems such as PET-CT have entered the clinical routine. Several clinical studies have evaluated the diagnostic accuracy of [F-18]FDG-PET-CT compared with the two imaging modalities alone and with both modalities assessed by side-by-side comparison, and reported a higher accuracy of the combined molecular imaging technique [126, 127]. Integrated PET-CT machines, enabling serial acquisition and subsequent display as a single fused image, are now commercially available and have shown improvement over PET alone in breast cancer assessment [128]. Although CT scanning provides high-resolution images with good anatomic details, it also has its limitations compared to MRI. MRI provides superior soft-tissue contrast, can provide functional information and does not impose radiation exposure on the patient. Therefore, within the last years, there have been efforts to combine the morphological high-resolution data of MRI with the functional data offered by PET. Today, there are just several experimental units that acquire the 2 scans simultaneously, and systems that could acquire and fuse MRI and PET scans are now commercially available [129, 130]. Nevertheless, there have been studies evaluating the feasibility of fused PET and MRI for the assessment of cancer patients. Domingues et al. [131] concluded that fused PET-MRI provides accurate morphological and functional data and that PET-MRI has the potential to emerge as an all-encompassing alternative to conventional multi-technique tumor staging. Moy et al. [132] investigated prone PET and fused PET-MRI. They found that prone PET scans were suitable for fusion with breast MRI. They demonstrated that the higher standardized uptake values (SUVs) provided by prone [F-18]-FDG-PET breast imaging in cancer detection were significantly different from those obtained in supine imaging alone and increased the confidence of the readers in lesion assessment [29]. The functional tumor information as well as assessment of nodal status combined with the anatomic localization provided by MRI yielded an improved diagnostic tool for the assessment of both primary and recurrent disease. However, in these studies, the functional information of [F-18]-FDG-PET was only combined with the morphological information of MRI in order to localize the tumor. The potentials of a multiparametric functional PET-MRI have not yet been explored. Figure 1 shows an overview of the multitude of functional information and metabolic activity that can be assessed with each imaging technique by PET/MRI. Basically, three different fields of application are feasible with combined molecular imaging techniques such as PET/MRI: (1) anatomy can be merged with functional information from PET; (2) the same functional parameter can be monitored simultaneously with PET and MRI; or (3) metabolic processes can be simultaneously observed at different levels [133]. In an ongoing study by Pinker et al., the potential of the assessment of multiple functional information with PET/MRI for an improved diagnosis 
and staging of breast lesions was evaluated [134, 135]. In this study [F-18]-FDG-PET was combined with different functional MRI methods (CE-MRI, DWI, and ${ }^{1} \mathrm{H}-\mathrm{MRSI}$ ) with high spatial and/or temporal resolution at $3 \mathrm{~T}$, and the preliminary results are promising: Molecular imaging of breast lesions by PET-MRI is feasible. PET-MRI seems to improve diagnostic confidence in the assessment of breast lesions and enables accurate assessment of the nodal status.

Today, PEM and PET-MRI of the breast is mainly performed using the rather nonspecific radiotracer [F-18]-FDG. However, currently, specific radiotracers are being developed that will allow tailored molecular imaging of breast cancer and that will target different metabolic processes within the tumor at different levels (fig. 1): FLT and FMAU are markers of cell proliferation and thus can image increased cell proliferation in breast cancer. [F-18]-FMISO is able to visualize tumor hypoxia whereas [F-18]-16- $\alpha$-fluoroestradiol-17- $\beta$ (FES) depicts estrogen receptor expression and thus has the potential to predict response to anti-hormonal therapy. In an animal model, Smith-Jones et al. demonstrated the feasibility of non-invasive assessment of HER2 expression in breast cancer by ${ }^{68} \mathrm{Ga}$-trastuzumab and its modification by therapy [136, 137]. In conclusion, it can be expected that these new specific radiotracers will offer new opportunities for evaluating breast cancer, bringing us closer to personalized cancer therapy.

\section{Conclusions}

Within the recent years, molecular imaging has entered the field of breast imaging comprising nuclear imaging modalities (BSGI, PEM), multiparametric MRI (CE-MRI, DWI, MRSI), combined imaging modalities (PET-MRI) as well as evolving techniques such as phosphorus spectroscopy and sodium imaging. Molecular imaging in breast cancer is still evolving and more significant advances in this field are imminent. It can be expected that, in the future, with molecular imaging techniques and tailored radiotracers targeting metabolic processes simultaneously at different levels, information on tumor biology such as neovascularity, apoptosis, and necrosis (fig. 1) can in future be acquired, and thus an improvement in pre-therapeutic diagnosis, assessment, and monitoring of responses to treatment will be possible.

\section{Acknowledgements}

Funding was provided by the Austrian Society of Senology Scientific Funding Price 2009, the Austrian Nationalbank 'Jubiläumsfond' Project Nos. 13652, 13834, 13629, and 13418, and the Medical Scientific Fund of the Mayor of Vienna Project No. 10029.

\section{Disclosure Statement}

The authors declare no conflicts of interests.

\section{References}

1 Weissleder R, Mahmood U: Molecular imaging. Radiology 2001;219:316-333.

2 Kolb TM, Lichy J, Newhouse JH: Occult cancer in women with dense breasts: Detection with screening US - diagnostic yield and tumor characteristics. Radiology 1998;207:191-199.

-3 Becherer A, Helbich T, Staudenherz A, Jakesz R, Kubista E, Lehner R, Rudas M, Teleky B, Kletter $\mathrm{K}$, Leitha T: The diagnostic value of planar and SPET scintimammography in different age groups. Nucl Med Commun 1997;18:710-718.

$\checkmark 4$ Helbich TH, Becherer A, Trattnig S, Leitha T, Kelkar P, Seifert M, Gnant M, Staudenherz A, Rudas M, Wolf G, Mostbeck GH: Differentiation of benign and malignant breast lesions: MR imaging versus Tc-99m sestamibi scintimammography. Radiology 1997;202:421-429.

$\checkmark 5$ Aktolun C, Bayhan H, Kir M: Clinical experience with Tc-99m mibi imaging in patients with malignant tumors. Preliminary results and comparison with Tl-201. Clin Nucl Med 1992;17:171-176.

6 Khalkhali I, Mena I, Jouanne E, Diggles L, Venegas R, Block J, Alle K, Klein S: Prone scintimammography in patients with suspicion of carcinoma of the breast. J Am Coll Surg 1994;178:491497.

7 Taillefer R: Clinical applications of $99 \mathrm{mTc}$ sestamibi scintimammography. Semin Nucl Med 2005;35:100-115.
8 Lumachi F, Ferretti G, Povolato M, Marzola MC, Zucchetta P, Geatti O, Brandes AA, Bui F: Accuracy of technetium-99m sestamibi scintimammography and $\mathrm{X}$-ray mammography in premenopausal women with suspected breast cancer. Eur J Nucl Med 2001;28:1776-1780.

9 Khalkhali I, Baum JK, Villanueva-Meyer J, Edell SL, Hanelin LG, Lugo CE, Taillefer R, Freeman LM, Neal CE, Scheff AM, Connolly JL, Schnitt SJ, Houlihan MJ, Sampalis JS, Haber SB: $(99 \mathrm{~m}) \mathrm{Tc}$ sestamibi breast imaging for the examination of patients with dense and fatty breasts: Multicenter study. Radiology 2002;222:149-155.

10 Cutrone JA, Khalkhali I, Yospur LS, Diggles L, Weinberg I, Pong EM, Tolmos J, Vargas MP, Vargas HI: Tc-99m sestamibi scintimammography for the evaluation of breast masses in patients with radiographically dense breasts. Breast $\mathrm{J}$ 1999;5:383-388.

11 Babuccu O, Peksoy I, Kargi E, Hosnuter M, Ozdemir H, Gundogdu S, Isikdemir A: The value of scintimammography in reduction mammaplasties: A preliminary study. Aesthetic Plast Surg 2003;27:296-300.

12 Arslan N, Ozturk E, Ilgan S, Urhan M, Karacalioglu O, Pekcan M, Tufan T, Bayhan H: 99Tcm-mibi scintimammography in the evaluation of breast lesions and axillary involvement: A comparison with mammography and histopathological diagnosis. Nucl Med Commun 1999;20:317-325.
13 Maffioli L, Agresti R, Chiti A, Crippa F, Gasparini M, Greco M, Bombardieri E: Prone scintimammography in patients with non-palpable breast lesions. Anticancer Res 1996;16:1269-1273.

14 Scopinaro F, Ierardi M, Porfiri LM, Tiberio NS, De Vincentis G, Mezi S, Cannas P, Gigliotti T, Marzetti L: 99mTc-mibi prone scintimammography in patients with high and intermediate risk mammography. Anticancer Res 1997;17:1635-1638.

15 Scopinaro F, Schillaci O, Ussof W, Nordling K, Capoferro R, De Vincentis G, Danieli R, Ierardi M, Picardi V, Tavolaro R, Colella AC: A three center study on the diagnostic accuracy of 99mTc-mibi scintimammography. Anticancer Res 1997;17:1631-1634.

16 Tolmos J, Cutrone JA, Wang B, Vargas HI, Stuntz M, Mishkin FS, Diggles LE, Venegas RJ, Klein SR, Khalkhali I: Scintimammographic analysis of nonpalpable breast lesions previously identified by conventional mammography. J Natl Cancer Inst 1998;90:846-849.

17 Palmedo H, Grunwald F, Bender H, Schomburg A, Mallmann P, Krebs D, Biersack HJ: Scintimammography with technetium-99m methoxyisobutylisonitrile: Comparison with mammography and magnetic resonance imaging. Eur J Nucl Med 1996;23:940-946.

18 Brem RF, Schoonjans JM, Kieper DA, Majewski S, Goodman S, Civelek C: Highresolution scintimammography: A pilot study. J Nucl Med 2002;43:909-915. 
19 Brem RF, Rapelyea JA, Zisman G, Mohtashemi K, Raub J, Teal CB, Majewski S, Welch BL: Occult breast cancer: Scintimammography with high-resolution breast-specific gamma camera in women at high risk for breast cancer. Radiology 2005;237:274-280.

20 Coover LR, Caravaglia G, Kuhn P: Scintimammography with dedicated breast camera detects and localizes occult carcinoma. J Nucl Med 2004;45:553-558.

-21 Rhodes DJ, O'Connor MK, Phillips SW, Smith RL, Collins DA: Molecular breast imaging: A new technique using technetium Tc $99 \mathrm{~m}$ scintimammography to detect small tumors of the breast. Mayo Clin Proc 2005;80:24-30.

-22 Brem RF, Floerke AC, Rapelyea JA, Teal C, Kelly $\mathrm{T}$, Mathur V: Breast-specific gamma imaging as an adjunct imaging modality for the diagnosis of breast cancer. Radiology 2008;247:651-657.

23 Brem RF, Shahan C, Rapleyea JA, Donnelly CA, Rechtman LR, Kidwell AB, Teal CB, McSwain A, Torrente J: Detection of occult foci of breast cancer using breast-specific gamma imaging in women with one mammographic or clinically suspicious breast lesion. Acad Radiol 2010;17:735-743.

24 Wahl RL: Current status of PET in breast cancer imaging, staging, and therapy. Semin Roentgenol 2001;36:250-260.

-25 Avril N, Bense S, Ziegler SI, Dose J, Weber W, Laubenbacher C, Romer W, Janicke F, Schwaiger M: Breast imaging with fluorine-18-FDG PET: Quantitative image analysis. J Nucl Med 1997;38:1186-1191.

26 Avril N, Menzel M, Dose J, Schelling M, Weber W, Janicke F, Nathrath W, Schwaiger M: Glucose metabolism of breast cancer assessed by ${ }^{18} \mathrm{~F}$-FDG PET: Histologic and immunohistochemical tissue analysis. J Nucl Med 2001;42:9-16.

-27 Bos R, van Der Hoeven JJ, van Der Wall E, van Der Groep P, van Diest PJ, Comans EF, Joshi U, Semenza GL, Hoekstra OS, Lammertsma AA, Molthoff CF: Biologic correlates of (18)fluorodeoxyglucose uptake in human breast cancer measured by positron emission tomography. J Clin Oncol 2002;20:379-387.

28 Schirrmeister H, Kuhn T, Guhlmann A, Santjohanser C, Horster T, Nussle K, Koretz K, Glatting G, Rieber A, Kreienberg R, Buck AC, Reske SN: Fluorine-18 2-deoxy-2-fluoro-D-glucose PET in the preoperative staging of breast cancer: Comparison with the standard staging procedures. Eur J Nucl Med 2001;28:351-358.

29 Goerres GW, Michel SC, Fehr MK, Kaim AH, Steinert HC, Seifert B, von Schulthess GK, KubikHuch RA: Follow-up of women with breast cancer: Comparison between MRI and FDG PET. Eur Radiol 2003;13:1635-1644.

-30 Rieber A, Schirrmeister H, Gabelmann A, Nuessle K, Reske S, Kreienberg R, Brambs HJ, Kuehn T: Pre-operative staging of invasive breast cancer with MR mammography and/or PET: Boon or bunk? Br J Radiol 2002;75:789-798.

-31 Murthy K, Aznar M, Thompson CJ, Loutfi A, Lisbona R, Gagnon JH: Results of preliminary clinical trials of the positron emission mammography system PEM-I: A dedicated breast imaging system producing glucose metabolic images using FDG. J Nucl Med 2000;41:1851-1858.
32 Levine EA, Freimanis RI, Perrier ND, Morton K, Lesko NM, Bergman S, Geisinger KR, Williams RC, Sharpe C, Zavarzin V, Weinberg IN, Stepanov PY, Beylin D, Lauckner K, Doss M, Lovelace J, Adler LP: Positron emission mammography: Initial clinical results. Ann Surg Oncol 2003;10:86-91.

33 Freifelder R, Karp JS: Dedicated PET scanners for breast imaging. Phys Med Biol 1997;42:24632480.

34 Rosen EL, Eubank WB, Mankoff DA: FDG PET, $\mathrm{PET} / \mathrm{CT}$, and breast cancer imaging. Radiographics 2007;27(suppl 1):S215-S229.

35 Rosen EL, Turkington TG, Soo MS, Baker JA, Coleman RE: Detection of primary breast carcinoma with a dedicated, large-field-of-view FDG PET mammography device: Initial experience. Radiology 2005;234:527-534.

36 Tafra L, Cheng Z, Uddo J, Lobrano MB, Stein W, Berg WA, Levine E, Weinberg IN, Narayanan D, Ross E, Beylin D, Yarnall S, Keen R, Sawyer K, Van Geffen J, Freimanis RL, Staab E, Adler LP, Lovelace J, Shen P, Stewart J, Dolinsky S: Pilot clinical trial of $18 \mathrm{~F}$-fluorodeoxyglucose positronemission mammography in the surgical management of breast cancer. Am J Surg 2005;190:628632 .

37 Berg WA, Weinberg IN, Narayanan D, Lobrano ME, Ross E, Amodei L, Tafra L, Adler LP, Uddo J, Stein W 3rd, Levine EA: High-resolution fluorodeoxyglucose positron emission tomography with compression ("positron emission mammography') is highly accurate in depicting primary breast cancer. Breast J 2006;12:309-323.

38 Schilling KJ, Conte PF, Adler LP, Tafra L: The role of positron emission mammography in breast cancer imaging and management. Appl Radiol 2008;37:26-36.

39 Fischer U, Kopka L, Brinck U, Korabiowska M, Schauer A, Grabbe E: Prognostic value of contrastenhanced MR mammography in patients with breast cancer. Eur Radiol 1997;7:1002-1005.

40 Warner E, Plewes DB, Hill KA, Causer PA, Zubovits JT, Jong RA, Cutrara MR, DeBoer G, Yaffe MJ, Messner SJ, Meschino WS, Piron CA, Narod SA: Surveillance of Brca1 and Brca2 mutation carriers with magnetic resonance imaging, ultrasound, mammography, and clinical breast examination. JAMA 2004;292:1317-1325.

41 Riedl CC, Ponhold L, Flory D, Weber M, Kroiss R, Wagner T, Fuchsjager M, Helbich TH: Magnetic resonance imaging of the breast improves detection of invasive cancer, preinvasive cancer, and premalignant lesions during surveillance of women at high risk for breast cancer. Clin Cancer Res 2007;13:6144-6152.

42 Drew PJ, Turnbull LW, Kerin MJ: Magneticresonance imaging for breast cancer. Lancet 1998; 351:1661-1662.

43 Kinkel K, Helbich TH, Esserman LJ, Barclay J, Schwerin EH, Sickles EA, Hylton NM: Dynamic high-spatial-resolution MR imaging of suspicious breast lesions: Diagnostic criteria and interobserver variability. AJR Am J Roentgenol 2000;175: $35-43$.

44 Morris EA: Diagnostic breast MR imaging: Current status and future directions. Radiol Clin North Am 2007:45:863-880, VII.

45 Stoutjesdijk MJ, Boetes C, Jager GJ, Beex L, Bult P, Hendriks JH, Laheij RJ, Massuger L, van Die LE, Wobbes T, Barentsz JO: Magnetic resonance imaging and mammography in women with a hereditary risk of breast cancer. J Natl Cancer Inst 2001;93:1095-1102.
6 Helbich TH: Contrast-enhanced magnetic resonance imaging of the breast. Eur J Radiol 2000;34:208219.

47 Heywang-Kobrunner SH, Viehweg P, Heinig A, Kuchler C: Contrast-enhanced MRI of the breast: Accuracy, value, controversies, solutions. Eur J Radiol 1997;24:94-108.

48 Heywang-Koebrunner SH, Viehweg P: Sensitivity of contrast-enhanced MR imaging of the breast. Magn Reson Imaging Clin N Am 1994;2:527-538.

49 Kaiser WA, Zeitler E: MR imaging of the breast: Fast imaging sequences with and without GDDTPA. Preliminary observations. Radiology 1989; 170:681-686.

50 Kuhl C: The current status of breast MR imaging Part I. Choice of technique, image interpretation, diagnostic accuracy, and transfer to clinical practice. Radiology 2007;244:356-378.

51 Kuhl CK: Breast MR imaging at 3T. Magn Reson Imaging Clin N Am 2007;15:315-320, VI.

52 Kuhl CK: Current status of breast MR imaging. Part 2. Clinical applications. Radiology 2007;244: 672-691.

53 Kuhl CK, Schild HH, Morakkabati N: Dynamic bilateral contrast-enhanced MR imaging of the breast: Trade-off between spatial and temporal resolution. Radiology 2005;236:789-800.

54 Liberman L, Morris EA, Lee MJ, Kaplan JB, LaTrenta LR, Menell JH, Abramson AF, Dashnaw SM, Ballon DJ, Dershaw DD: Breast lesions detected on MR imaging: Features and positive predictive value. AJR Am J Roentgenol 2002;179:171-178.

55 Turnbull LW: Dynamic contrast-enhanced MRI in the diagnosis and management of breast cancer. NMR Biomed 2008;22:28-39.

56 Esserman L, Wolverton D, Hylton N: Magnetic resonance imaging for primary breast cancer management: Current role and new applications. Endocr Relat Cancer 2002;9:141-153.

57 Pinker K, Grabner G, Bogner W, Gruber S, Szomolanyi P, Trattnig S, Heinz-Peer G, Weber M, Fitzal F, Pluschnig U, Rudas M, Helbich T: A combined high temporal and high spatial resolution 3 Tesla MR imaging protocol for the assessment of breast lesions: Initial results. Invest Radiol 2009;44:553-558.

-58 Stadlbauer A, Bernt R, Gruber S, Bogner W, Pinker K, van der Riet W, Haller J, Salomonowitz E: Diffusion-weighted MR imaging with background body signal suppression (DWIBS) for the diagnosis of malignant and benign breast lesions. Eur Radiol 2009;19:2349-2356.

59 Bartella L, Huang W: Proton $\left({ }^{1} \mathrm{H}\right)$ MR spectroscopy of the breast. Radiographics 2007;27(suppl 1):S241-S252.

60 Bartella L, Morris EA: Advances in breast imaging: Magnetic resonance imaging. Curr Oncol Rep 2006;8:7-13.

61 Bartella L, Morris EA, Dershaw DD, Liberman L, Thakur SB, Moskowitz C, Guido J, Huang W: Proton MR spectroscopy with choline peak as malignancy marker improves positive predictive value for breast cancer diagnosis: Preliminary study. Radiology 2006;239:686-692.

62 Bartella L, Smith CS, Dershaw DD, et al.: Imaging breast cancer. Radiol Clin North Am 2007;45: 45-67. 
63 Meisamy S, Bolan PJ, Baker EH, Bliss RL, et al.: Neoadjuvant chemotherapy of locally advanced breast cancer: predicting response with in vivo (1) h MR spectroscopy - a pilot study at $4 \mathrm{~T}$. Radiology 2004;233:424-431.

-64 Bartella L, Smith CS, Dershaw DD, Liberman L: Imaging breast cancer. Radiol Clin North Am 2007;45:45-67.

-65 Meisamy S, Bolan PJ, Baker EH, Bliss RL, Gulbahce E, Everson LI, Nelson MT, Emory TH, Tuttle TM, Yee D, Garwood M: Neoadjuvant chemotherapy of locally advanced breast cancer: Predicting response with in vivo (1)H MR spectroscopy - a pilot study at 4 T. Radiology 2004;233:424-431.

66 Meisamy S, Bolan PJ, Baker EH, Pollema MG, Le CT, Kelcz F, Lechner MC, Luikens BA, Carlson RA, Brandt KR, Amrami KK, Nelson MT, Everson LI, Emory TH, Tuttle TM, Yee D, Garwood M: Adding in vivo quantitative ${ }^{1} \mathrm{H}$ MR spectroscopy to improve diagnostic accuracy of breast MR imaging: Preliminary results of observer performance study at $4.0 \mathrm{~T}$. Radiology 2005;236:465-475.

-67 Bogner W, Pinker K, Gruber S, Grabner G, Stadlbauer A, Weber M, Moser E, Helbich TH, Trattnig S: Diffusion-weighted MRI for differentiation of breast lesions at 3.0 Tesla: How does selection of diffusion schemes affect diagnosis? Radiology 2009;253:341-351.

-68 Guo Y, Cai YQ, Cai ZL, Gao YG, An NY, Ma L, Mahankali S, Gao JH: Differentiation of clinically benign and malignant breast lesions using diffusion-weighted imaging. J Magn Reson Imaging 2002;16:172-178.

69 Woodhams R, Matsunaga K, Kan S, Hata H, Ozaki M, Iwabuchi K, Kuranami M, Watanabe M, Hayakawa K: ADC mapping of benign and malignant breast tumors. J Magn Reson Med Sci 2005;4:3542.

70 Mann RM, Kuhl CK, Kinkel K, Boetes C: Breast MRI: Guidelines from the European Society of Breast Imaging. Eur Radiol 2008;18:1307-1318.

71 Vomweg TW, Teifke A, Schreiber WG, Schmidt M, Thelen M: [Combination of low and high resolution T1-weighted sequences for improved evaluation of morphologic criteria in dynamic contrast enhanced MRI of the breast]. Rofo 2002:174:14451449.

-72 Veltman J, Stoutjesdijk M, Mann R, Huisman HJ, Barentsz JO, Blickman JG, Boetes C: Contrastenhanced magnetic resonance imaging of the breast: The value of pharmacokinetic parameters derived from fast dynamic imaging during initial enhancement in classifying lesions. Eur Radio 2008;18:1123-1133.

73 Goto M, Ito H, Akazawa K, Kubota T, Kizu O, Yamada K, Nishimura T: Diagnosis of breast tumors by contrast-enhanced MR imaging: Comparison between the diagnostic performance of dynamic enhancement patterns and morphologic features. J Magn Reson Imaging 2007;25:104-112.

74 Schnall MD, Blume J, Bluemke DA, DeAngelis GA, DeBruhl N, Harms S, Heywang-Kobrunner SH, Hylton N, Kuhl CK, Pisano ED, Causer P, Schnitt SJ, Thickman D, Stelling CB, Weatherall PT, Lehman C, Gatsonis CA: Diagnostic architectural and dynamic features at breast MR imaging: Multicenter study. Radiology 2006;238:42-53.

-75 Schnall MD, Rosten S, Englander S, Orel SG, Nunes LW: A combined architectural and kinetic interpretation model for breast MR images. Acad Radiol 2001;8:591-597.
76 Kuhl CK, Jost P, Morakkabati N, Zivanovic O, Schild HH, Gieseke J: Contrast-enhanced MR imaging of the breast at 3.0 and $1.5 \mathrm{~T}$ in the same patients: Initial experience. Radiology 2006; 239:666-676.

77 Noebauer-Huhmann IM, Pinker K, Barth M, Mlynarik V, Ba-Ssalamah A, Saringer WF, Weber M, Benesch T, Witoszynskyj S, Rauscher A, Reichenbach JR, Trattnig S: Contrast-enhanced, high-resolution, susceptibility-weighted magnetic resonance imaging of the brain: Dose-dependent optimization at 3 Tesla and 1.5 Tesla in healthy volunteers. Invest Radiol 2006;41:249-255.

78 Pinker K, Ba-Ssalamah A, Wolfsberger S, Mlynarik V, Knosp E, Trattnig S: The value of high-field MRI (3T) in the assessment of sellar lesions. Eur J Radiol 2005;54:327-334.

79 Ba-Ssalamah A, Nobauer-Huhmann IM, Pinker K, Schibany N, Prokesch R, Mehrain S, Mlynarik V, Fog A, Heimberger K, Trattnig S: Effect of contrast dose and field strength in the magnetic resonance detection of brain metastases. Invest Radiol 2003;38:415-422.

80 Kuhl CK, Kooijman H, Gieseke J, Schild HH: Effect of B1 inhomogeneity on breast imaging at 3.0 T. Radiology 2007;244:929-930.

81 Rakow-Penner R, Daniel B, Yu H, Sawyer-Glover A, Glover GH: Relaxation times of breast tissue at $1.5 \mathrm{~T}$ and $3 \mathrm{~T}$ measured using IDEAL. J Magn Reson Imaging 2006;23:87-91.

82 Su MY, Baik HM, Yu HJ, Chen JH, Mehta RS, Nalcioglu O: Comparison of choline and pharmacokinetic parameters in breast cancer measured by MR spectroscopic imaging and dynamic contrast enhanced MRI. Technol Cancer Res Treat 2006:5:401-410.

83 Jacobs MA, Barker PB, Bottomley PA, Bhujwalla $\mathrm{Z}$, Bluemke DA: Proton magnetic resonance spectroscopic imaging of human breast cancer: A preliminary study. J Magn Reson Imaging 2004; 19:68-75.

84 Tozaki M: Proton MR spectroscopy of the breast. Breast Cancer 2008;15:218-223.

85 Roebuck JR, Cecil KM, Schnall MD, Lenkinski RE: Human breast lesions: Characterization with proton MR spectroscopy. Radiology 1998;209:269275.

86 Kvistad KA, Bakken IJ, Gribbestad IS, Ehrnholm B, Lundgren S, Fjosne HE, Haraldseth O: Characterization of neoplastic and normal human breast tissues with in vivo (1)H MR spectroscopy. J Magn Reson Imaging 1999;10:159-164.

87 Cecil KM, Schnall MD, Siegelman ES, Lenkinski RE: The evaluation of human breast lesions with magnetic resonance imaging and proton magnetic resonance spectroscopy. Breast Cancer Res Treat 2001;68:45-54.

88 Yeung DK, Cheung HS, Tse GM: Human breast lesions: Characterization with contrast-enhanced in vivo proton MR spectroscopy - initial results. Radiology 2001;220:40-46.

89 Jagannathan NR, Kumar M, Seenu V, Coshic O, Dwivedi SN, Julka PK, Srivastava A, Rath GK: Evaluation of total choline from in-vivo volume localized proton MR spectroscopy and its response to neoadjuvant chemotherapy in locally advanced breast cancer. Br J Cancer 2001;84:1016-1022.

90 Tse GM, Cheung HS, Pang LM, Chu WC, Law BK, Kung FY, Yeung DK: Characterization of lesions of the breast with proton MR spectroscopy: Comparison of carcinomas, benign lesions, and phyllodes tumors. AJR Am J Roentgenol 2003;181:1267-1272.
91 Gruber S, Debski B, Pinker K, Chmelik M, Grabner G, Helbich T, Trattnig S, Bogner W: Three dimensional proton magnetic resonance spectroscopic imaging (3D-MRSI) for differentiation of benign and malignant breast lesions at 3 Tesla. Radiology 2011, in press.

92 Podo F: Tumour phospholipid metabolism. NMR Biomed 1999;12:413-439.

93 Ackerstaff E, Pflug BR, Nelson JB, Bhujwalla ZM: Detection of increased choline compounds with proton nuclear magnetic resonance spectroscopy subsequent to malignant transformation of human prostatic epithelial cells. Cancer Res 2001;61:3599-3603.

94 Barzilai A, Horowitz A, Geier A, Degani H: Phosphate metabolites and steroid hormone receptors of benign and malignant breast tumors. A nuclear magnetic resonance study. Cancer 1991;67:2919-2925.

95 Arias-Mendoza F, Smith MR, Brown TR: Predicting treatment response in non-Hodgkin's lymphoma from the pretreatment tumor content of phosphoethanolamine plus phosphocholine. Acad Radiol 2004;11:368-376.

96 Arias-Mendoza F, Zakian K, Schwartz A, Howe FA, Koutcher JA, Leach MO, Griffiths JR, Heerschap A, Glickson JD, Nelson SJ, Evelhoch JL, Charles HC, Brown TR: Methodological standardization for a multi-institutional in vivo trial of localized ${ }^{31} \mathrm{P}$ MR spectroscopy in human cancer research. In vitro and normal volunteer studies. NMR Biomed 2004;17:382-391.

97 Eis M, Els T, Hoehn-Berlage M, Hossmann KA: Quantitative diffusion MR imaging of cerebral tumor and edema. Acta Neurochir Suppl (Wien) 1994;60:344-346.

98 Frangioni JV: New technologies for human cancer imaging. J Clin Oncol 2008;26:4012-4021.

99 Bogner W, Pinker K, Gruber S, Grabner G, Helbich TH, Trattnig S: High-field diffusionweighted imaging for improved differentiation of benign and malignant breast lesions: Chicago, RSNA, 2008.

100 Conturo TE, McKinstry RC, Aronovitz JA, Neil JJ: Diffusion MRI: Precision, accuracy and flow effects. NMR Biomed 1995;8:307-332.

101 Koh DM, Collins DJ: Diffusion-weighted MRI in the body: Applications and challenges in oncology. AJR Am J Roentgenol 2007;188:1622-1635.

102 Thoeny HC, De Keyzer F: Extracranial applications of diffusion-weighted magnetic resonance imaging. Eur Radiol 2007;17:1385-1393.

103 Ichikawa T, Erturk SM, Motosugi U, Sou H, Iino H, Araki T, Fujii H: High-B-value diffusionweighted MRI in colorectal cancer. AJR Am J Roentgenol 2006;187:181-184.

104 Tamai K, Koyama T, Saga T, Morisawa N, Fujimoto K, Mikami Y, Togashi K: The utility of diffusion-weighted MR imaging for differentiating uterine sarcomas from benign leiomyomas. Eur Radiol 2008;18:723-730.

105 Tamai K, Koyama T, Saga T, Umeoka S, Mikami Y, Fujii S, Togashi K: Diffusion-weighted MR imaging of uterine endometrial cancer. J Magn Reson Imaging 2007;26:682-687.

106 Kartalis N, Lindholm TL, Aspelin P, Permert J, Albiin N: Diffusion-weighted magnetic resonance imaging of pancreas tumours. Eur Radiol 2009;19:1981-1990 
107 Naganawa S, Sato C, Nakamura T, Kumada H, Ishigaki T, Miura S, Maruyama K, Takizawa $\mathrm{O}$ Diffusion-weighted images of the liver: Comparison of tumor detection before and after contrast enhancement with superparamagnetic iron oxide. J Magn Reson Imaging 2005;21:836-840.

108 Sato C, Naganawa S, Nakamura T, Kumada H, Miura S, Takizawa O, Ishigaki T: Differentiation of noncancerous tissue and cancer lesions by apparent diffusion coefficient values in transition and peripheral zones of the prostate. J Magn Reson Imaging 2005;21:258-262.

109 Marini C, Iacconi C, Giannelli M, Cilotti A, Moretti M, Bartolozzi C: Quantitative diffusionweighted MR imaging in the differential diagnosis of breast lesion. Eur Radiol 2007;17:2646-2655.

-110 Guo Y, Cai YQ, Cai ZL, Gao YG, An NY, Ma L, Mahankali S, Gao JH: Differentiation of clinically benign and malignant breast lesions using diffusion-weighted imaging. J Magn Reson Imaging 2002;16:172-178.

-111 Yankeelov TE, Lepage M, Chakravarthy A, Broome EE, Niermann KJ, Kelley MC, Meszoely I, Mayer IA, Herman CR, McManus K, Price RR, Gore JC: Integration of quantitative DCE-MRI and ADC mapping to monitor treatment response in human breast cancer: Initial results. Magn Reson Imaging 2007;25:1-13.

112 Woodhams R, Matsunaga K, Iwabuchi K, Kan S, Hata H, Kuranami M, Watanabe M, Hayakawa K: Diffusion-weighted imaging of malignant breast tumors - the usefulness of apparent diffusion coefficient (ADC) value and ADC map for the detection of malignant breast tumors and evaluation of cancer extension. J Comput Assist Tomogr 2005;29:644-649.

113 Kim RJ, Chen EL, Lima JA, Judd RM: Myocardial GD-DTPA kinetics determine MRI contrast enhancement and reflect the extent and severity of myocardial injury after acute reperfused infarction. Circulation 1996;94:3318-3326.

-114 Kim RJ, Judd RM, Chen EL, Fieno DS, Parrish TB, Lima JA: Relationship of elevated ${ }^{23} \mathrm{Na}$ magnetic resonance image intensity to infarct size after acute reperfused myocardial infarction. Circulation 1999;100:185-192.

-115 Kim RJ, Lima JA, Chen EL, Reeder SB Klocke FJ, Zerhouni EA, Judd RM: Fast ${ }^{23} \mathrm{Na}$ magnetic resonance imaging of acute reperfused myocardial infarction. Potential to assess myocardial viability. Circulation 1997;95:1877-1885.
116 Ouwerkerk R, Bleich KB, Gillen JS, Pomper MG, Bottomley PA: Tissue sodium concentration in human brain tumors as measured with ${ }^{23} \mathrm{Na} \mathrm{MR}$ imaging. Radiology 2003;227:529-537.

117 Ouwerkerk R: Sodium magnetic resonance imaging: From research to clinical use. J Am Coll Radiol 2007;4:739-741.

118 Ouwerkerk R, Jacobs MA, Macura KJ, Wolff AC, Stearns V, Mezban SD, Khouri NF, Bluemke DA, Bottomley PA: Elevated tissue sodium concentration in malignant breast lesions detected with non-invasive ${ }^{23} \mathrm{Na}$ MRI. Breast Cancer Res Treat 2007;106:151-160.

119 Cameron IL, Smith NK, Pool TB, Sparks RL: Intracellular concentration of sodium and other elements as related to mitogenesis and oncogenesis in vivo. Cancer Res 1980;40:1493-1500.

120 Nagy I, Lustyik G, Lukacs G, Nagy V, Balazs G: Correlation of malignancy with the intracellular $\mathrm{Na}+\mathrm{K}+$ ratio in human thyroid tumors. Cancer Res 1983;43:5395-5402.

121 Zangheri B, Messa C, Picchio M, Gianolli L, Landoni C, Fazio F: PET/CT and breast cancer. Eur J Nucl Med Mol Imaging 2004;31(suppl 1):S135-S142.

122 Hathaway PB, Mankoff DA, Maravilla KR, Austin-Seymour MM, Ellis GK, Gralow JR, Cortese AA, Hayes CE, Moe RE: Value of combined FDG PET and MR imaging in the evaluation of suspected recurrent local-regional breast cancer: Preliminary experience. Radiology 1999;210:807-814.

123 Hoh CK: Clinical use of FDG PET. Nucl Med Biol 2007;34:737-742.

124 Duch J, Fuster D, Munoz M, Fernandez PL, Paredes P, Fontanillas M, Guzman F, Rubi S, Lomena FJ, Pons F: (18)F-FDG PET/CT for early prediction of response to neoadjuvant chemotherapy in breast cancer. Eur J Nucl Med Mol Imaging 2009;36:1551-1557.

125 Escalona S, Blasco JA, Reza MM, Andradas E, Gomez N: A systematic review of FDG-PET in breast cancer. Med Oncol 2010;27:114-129.

126 Antoch G, Saoudi N, Kuehl H, Dahmen G, Mueller SP, Beyer T, Bockisch A, Debatin JF, Freudenberg LS: Accuracy of whole-body dualmodality fluorine-18-2-fluoro-2-deoxy-D-glucose positron emission tomography and computed tomography (FDG-PET/CT) for tumor staging in solid tumors: Comparison with CT and PET. J Clin Oncol 2004;22:4357-4368.
127 Bar-Shalom R, Yefremov N, Guralnik L, Gaitini D, Frenkel A, Kuten A, Altman H, Keidar Z, Israel O: Clinical performance of PET/CT in evaluation of cancer: Additional value for diagnostic imaging and patient management. J Nucl Med 2003;44:1200-1209.

128 Tatsumi M, Cohade C, Mourtzikos KA, Fishman EK, Wahl RL: Initial experience with FDG-PET/ $\mathrm{CT}$ in the evaluation of breast cancer. Eur J Nucl Med Mol Imaging 2006;33:254-262.

129 Pichler BJ, Judenhofer MS, Catana C, Walton JH, Kneilling M, Nutt RE, Siegel SB, Claussen CD, Cherry SR: Performance test of an LSO-APD detector in a 7-T MRI scanner for simultaneous PET/MRI. J Nucl Med 2006;47:639-647.

130 Wehrl HF, Judenhofer MS, Wiehr S, Pichler BJ Pre-clinical PET/MR: Technological advances and new perspectives in biomedical research. Eur $\mathrm{J}$ Nucl Med Mol Imaging 2009;36(suppl 1):S56-S68.

131 Domingues RC, Carneiro MP, Lopes FC, da Fonseca LM, Gasparetto EL: Whole-body MRI and FDG PET fused images for evaluation of patients with cancer. AJR Am J Roentgenol 2009;192:1012-1020.

132 Moy L, Ponzo F, Noz ME, Maguire GQ Jr, Murphy-Walcott AD, Deans AE, Kitazono MT, Travascio L, Kramer EL: Improving specificity of breast MRI using prone PET and fused MRI and PET 3D volume datasets. J Nucl Med 2007;48:528-537.

133 Antoch G, Bockisch A: Combined PET/MRI: A new dimension in whole-body oncology imaging? Eur J Nucl Med Mol Imaging 2009;36(suppl 1):S113-S120.

134 Pinker K, Karanikas G, Mayerhoefer M, El-Rabadi K, Schernthaner M, Helbich TH: Molecular imaging in breast lesions: Comparison of dedicated breast 18F-FDG-PET-CT vs. contrast-enhanced MRI at 3 Tesla. Vienna, ECR, 2010.

135 Pinker K, Bogner W, Trattnig S, Karanikas G, Gruber S, Helbich TH: Molecular imaging of breast lesions with PET-MRI: Proof of concept. Vienna, ECR, 2010.

136 Smith-Jones PM, Solit D, Afroze F, Rosen N, Larson SM: Early tumor response to Hsp90 therapy using HER2 PET: Comparison with 18F-FDG PET. J Nucl Med 2006:47:793-796.

137 Smith-Jones PM, Solit DB, Akhurst T, Afroze F, Rosen N, Larson SM: Imaging the pharmacodynamics of HER2 degradation in response to Hsp90 inhibitors. Nat Biotechnol 2004;22:701-706. 